\title{
Early Intervention in Early Childhood Special Education According to Parents: A Qualitative Study
}

\section{Rukiye Konuk Er ${ }^{1}$}

${ }^{1}$ Asisst. Prof. Dr., Necmettin Erbakan University,

Konya/Turkey

ORCID: 0000-0002-9500-0534

E-Mail:

rukiyekonuk@gmail.com

Corresponding Author: Rukiye Konuk Er

January 2022

Volume:19

Issue: 45

DOI: $10.26466 / /$ opusjsr.1063400

Citation:

Konuk Er, R. (2022). Early intervention in early childhood special education according to parents: A qualitative study

OPUS- Journal of Society Research, 19(45), 103-115.

\begin{abstract}
Early intervention practices have an important place in early childhood special education practices as in every period. This study aims to examine the early intervention process of parents who have children with special needs during early childhood, the problems they experience and the solution suggestions to these problems. The study was conducted in qualitative research design. 53 parents participated in the research. As a result of the analysis of the opinions obtained with the semi-structured interview form, 6 themes and categories that were related to these themes were determined. When the special need of the child was found, it was seen that more opinions were expressed in the categories of "hospital/doctor" regarding the first person and/or institution theme. The other category in terms of the meaning of early intervention was "starting treatment/education early for the existing situation/problem". In addition, the category of "leaving it to time and helping with one's own competence" for the theme of struggling with the difficulties experienced also emphasizes how guidance is necessary and important. It was suggested that early intervention and pregnancy screening and the next process should be carried out with guidance.
\end{abstract}

Key Words: Special Education, Child with Special Needs, Early Intervention, Early Childhood, Parents.

Öz

Erken müdahale uygulamaları her dönemde olduğu gibi erken çocukluk dönemi özel eğitim uygulamaları için de önemli bir yer tutmaktadır. Bu çalışma ile de erken çocukluk döneminde özel eğitim gerektiren çocuğu olan ebeveynlerin nasıl bir erken müdahale süreci ile karşılaştıkları, bu sırada yaşadıkları ve çözüm önerilerinin incelenmesi amaçlanmıştır. Araştırma nitel araştırma deseninde yürütülmüştür. Araştırmanın çalışma gurubunu farkl engel türünde çocuğu olan 53 ebeveyn oluşturmuştur. Araştırmacı tarafından hazırlanan yarı yapılandırılmış görüşme formu ile elde edilen görüşlerin analizi sonucu 6 tema ve bunlara bağh kategoriler belirlenmiştir. Ebeveynlerin çocuklarnın özel durumunu öğrenildiklerinde ilk başvurulan kişi velveya kurum temasına yönelik "hastane/doktor" kategorisinde, erken müdahalenin anlamı temasına ilişkin ise "var olan durum/problem için tedaviyeleğitime erken başlamak" kategorilerine yönelik daha fazla görüş belirttikleri saptanmıştır. Ayrıca yaşanılan güçlüklerle mücadele etme temasına yönelik "zamana bırakma ve kendi yeterliği ile yardımcı olma" kategorisi de rehberliğin gerekliliğini ve önemini vurgulamaktadır. Erken müdahale ile gebelik taramalarının ve sonraki sürecin rehberlik ile birlikte yapılması gerektiŏi önerilmektedir.

Anahtar Kelimeler: Özel Eğitim, Özel Eğitim Gerektiren Çocuk, Erken Müdahale, Erken Çocukluk Dönemi, Ebeveyn. 


\section{Introduction}

The development process affected adversely during early childhood causes children to experience developmental delay, developmental deficiency (inability to show the skills expected from their age in basic developmental areas) and/or risk (Aytekin \& Bayhan, 2015; Temiz \& Akman, 2015). With the interventions offered in this process, it is aimed to support the development and health of children with developmental disabilities or who are at risk, to increase the existing competencies, to remove or reduce the limitations experienced, and to improve parenting skills of their parents (Bate, 2017; Kılıçkaya \& Zelyurt, 2015).

In early intervention, which has a very important place in early childhood special education practices, the importance of parent-child interaction, providing education opportunities to families and empowering parents is emphasized (Aslan, 2015; Bailey et al., 1999; Dunst, 2007; Guralnick, 2005; Kennedy et al., 2011). Early intervention is a support program for young children and their families that includes health and social services, in which families and field experts collaborate (Bari, Abdullah, Abdullah, \& Yasin 2016; García-Grau, Martínez-Rico, McWilliam, \& Cañadas Pérez, 2020). The early intervention programs offered during this period (such as boosting development of children, the active participation of parents within the process, reducing social problems in the country, and financial support) contributes to children, families and countries in in the short and long term (Bağlama \& Sakall1-Demirok, 2016; Diken, Bayhan, Turan, Sipal, Sucuoğlu, Ceber-Bakkaloğlu, Günel, \& Kara 2012; Kılıçkaya \& Zelyurt, 2015; KüçükDoğaroğlu \& Bapoğlu-Dümenci, 2015; Reynolds 2000; Sazak-Pınar, 2006; https://ailevecalisma.gov.tr). Children who are diagnosed in the early childhood period also get the chance to benefit from early intervention and special education services earlier. Parents have serious responsibilities for providing these early intervention practices as children learn many skills from their families beginning from the moment they are born and especially until they become a part of different social environments (such as school) (Bruder, Dunst, \& Mogro-Wilson, 2011; Campbell, \& Sawyer, 2009; Gül \& Diken, 2009; Kılınç, \& Aral, 2015; Selimoğlu, \& Özdemir 2018; Temiz, \& Akman, 2015; Tunçeli, \& Zembat, 2017). Therefore, it is vital to provide interventions to support the development of children with special needs or these children's parents to ensure that these interventions reach them quickly.

Although studies show that early intervention programs offer positive long-term outcomes (such as enabling children to benefit from early intervention strategies, reducing the problems that may occur in the future, benefiting from the support provided by families during the early intervention process, encouraging teachers to work with different disciplines) on teachers, parents, and especially children (Baglama \& Sakall1-Demirok, 2016; García-Grau et al., 2020; Pretis, 2009; Reynolds, 2000; Reynolds, Temple, \& Ou 2003; Sandberg, Norling, \& Lillvist, 2009), it is stated that different issues (such as not providing early intervention services on time, delays in the diagnosis of children, insufficient communication between institutions, not informing parents about existing services, lack of social sensitivity) regarding early intervention services continue in many countries (Aslan, 2015; Bari et al., 2016; Bruder, Dunst, \& Mogro-Wilson, 2011; Diken et al., 2012; Pang and Richey 2005; Powell, 2019; Pratis, 2009; Zheng, Maude \& Brotherson, 2015).

Early intervention is a support program in which families and field experts cooperate. This cooperation has an important role in meeting the parenting goals of the family that takes care of the child in early childhood. The early initiation of these support program(s) for children with special needs and the determination of the views of parents, who are the main implementers of the programs, will enable the issue to be addressed more fundamentally. For this reason, providing expert support to families in order to answer questions of parents, finding solutions to their problems, eliminating learning deficiencies caused by disability at the maximum level, revealing strengths of chilren and ensuring their participation in society at an early age are the factors that make early intervention important. 
With this study, we aimed to reveal how parents overcome this process beginning from the moment at which they learn that they have a child with special needs and the main problems experienced during this process in the early childhood period, which covers the critical process in life and provides a quality life standard. For this reason, the purpose of the present study was to determine when did the parents learn about the special needs of their children and what did they experience in early intervention services, and their suggestions related to the subject.

\section{Method}

\section{Research model}

The present study was carried out in a qualitative case study design in order to obtain multidimensional information about early intervention from parents. Qualitative research emphasizes meanings, experiences, and definitions. Comprehensive and detailed data consists entirely of words that people describe and observe (Coolican, 1992). In the qualitative case study design, the elements related to a situation are handled with a holistic approach, focusing on how they affect the related situation and how it is affected by the relevant situation (Creswell, 2012; Yıldırım \& Şimşek, 2008).

\section{Study group}

The study group consists of parents selected by purposive sampling method, as it aims to determine opinions of parents who have children needing special education during early childhood, about the early intervention process. The study group of the research was selected by criterion sampling, which is one of the purposive sampling method (Yıldırım \& Şimşek, 2005). In this way, we aimed to reflect people's experiences. In the determination of the sample group, the fact that the children are in early childhood and in need of special education, as well as willingness of participate were taken into consideration as the basic criteria. In addition, an informed consent form was obtained from the parents. Parents participating in the study had children with intellectual disability at mild and moderate level (especially Down Syndrome), with learning disability, autism spectrum disorder, attention deficit and hyperactivity, and with both physical and intellectual disabilities. There were 53 parents in the study group. The features of parents participated in the study and their children are given in Table 1.

Table 1. Demographic Characteristics of the Parents and Children in the Study Group

\begin{tabular}{|c|c|c|c|c|c|c|c|c|c|c|c|c|c|c|c|}
\hline & \multicolumn{4}{|c|}{ Parent's Age } & \multicolumn{3}{|c|}{$\begin{array}{l}\text { Parent's } \\
\text { Educational Status }\end{array}$} & \multicolumn{2}{|c|}{ Child's Age } & \multicolumn{3}{|c|}{$\begin{array}{l}\text { Child's Birth } \\
\text { Order }\end{array}$} & \multicolumn{3}{|c|}{ Child's Educational Background } \\
\hline & 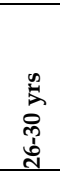 & 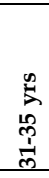 & $\begin{array}{l}\text { f̣ } \\
\text { d. }\end{array}$ & $\underset{F}{+}$ & है & 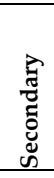 & 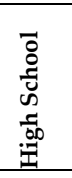 & ì & 官 & 营 & $\frac{\tilde{\sigma}}{\tilde{z}}$ & 㞼 & $\begin{array}{l}\text { Support } \\
\text { Education }\end{array}$ & $\begin{array}{l}\text { Inclusive and } \\
\text { support } \\
\text { education } \\
\text { (kinder-garten) }\end{array}$ & $\begin{array}{l}\text { Inclusive and } \\
\text { support } \\
\text { education } \\
\text { (Primary 1st } \\
\text { grade) }\end{array}$ \\
\hline 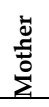 & 6 & 9 & 10 & 5 & 13 & 7 & 10 & 11 & 42 & 16 & 10 & 27 & 16 & 18 & 19 \\
\hline 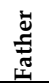 & 2 & 7 & 6 & 8 & 14 & 3 & 6 & & & & & & & & \\
\hline
\end{tabular}

\section{Data collection tool}

The "Structured Interview Form for Early Intervention in Early Childhood Special Education" developed by the researcher was used as a data collection tool in the study. Relevant literature was searched for the preparation of the form. During the research, the issue of early intervention in special education was emphasized and an interview form was prepared considering the studies on the subject. Opinions of 
experts were taken for the items determined in the interview form been prepared. The questions in the Structured Interview Form for Early Intervention in Early Childhood Special Education were rearranged depending on the feedback received from five experts, two of whom were lecturers in special education and three of whom were teachers in child development. Their opinions revealed that the study was appropriate, understandable and applicable. As a result of the pilot study conducted with three parents, the interview form was found to be appropriate. The form consists of two parts; demographic information is involved in the first part. In the second part, questions that help to determine the opinions of parents regarding early intervention are involved. In the interview form; questions which are asked to determine opinions of parents about early intervention in general, to whom or where they apply first when they learn about their child, what their child experience during and after the diagnosis, how they struggle during this process, and their suggestions regarding the difficulties they experience are involved. Applications were taken from parents in written form by the researcher herself, who is an expert in the field of early childhood special education. It is important for validity to include direct quotations from individuals and explain the results based on them. For this, some of the data obtained from the research was given as they were expressed to provide credibility (Wolcott, 1990). In addition, for the reliability study, an expert from early intervention field was asked to compare the same themes with the conceptual categories so that no themes were left out. The consistency of the comparisons made by the expert and the researcher was checked separately.

\section{Data collection process}

In order to collect the data, interviews were held in a special education and rehabilitation center where the participants would feel comfortable. Interviews were arranged with the parents (having a child who needs special education in early childhood) who met the criteria suitable for the purpose of the research, among the officials of the institution who were interviewed by appointment before. The study was carried out individually, with parents who wanted to voluntarily participate in the study among the informed parents. An explanation was prepared for the interviews, and the purpose of the research and how the study would be carried out were re-stated in the explanation in individual interviews. In addition, it was emphasized that the identities of the participants will be kept confidential. Written interview forms were used during the interviews. The interviews took between 25-35 minutes.

\section{Analysis and interpretation of data}

Collected data were analyzed using descriptive analysis technique. The main purpose here is to reach the concepts and relationships that can explain the collected data. By focusing on the collected data, codes are extracted from the themes that are frequently repeated and emphasized in the data. The face-to-face interviews made by the researcher were written down and read one by one. In this reading, the aim of the research and the prepared interview questions were taken into consideration. In the end of the reading, certain codes have emerged for each interview. In the process, the data were both fragmented and at the same time the integrity of meaning was preserved. After reading all the transcripts and completing the coding, the researcher created categories from the codes and the themes from the categories. Reliability was provided by getting help from an expert from the field for the consistency study between coders. The views were systematically separated and each interview was numbered starting from one. Words, sentences and paragraphs were conceptualized and coded within the framework of the purpose of the research and interview questions in order to determine the thought to be expressed while reading the data (Baltac1,2019; Brott \& Myers ,2002; Coolican, 1992; Tavşancıl \& Arslan, 2001; Yıldırım \& Şimşek, 2005).

\section{Research Validity-Reliability and Ethical Issues}

More than one strategy was used to ensure validity and reliability in the study. The first of these was 
prepared in line with the opinions of three faculty members in the field of special education and three experts in the field of child development in order to ensure the validity of the interview form. Participant confirmation is very essential to increase the validity and reliability of qualitative data. In addition, intense descriptions were included in the description of a situation by providing details to ensure validity in the research or while giving information about a theme (Creswell, 2012). This helps the reader decide whether the results can be transfered to other media. In qualitative researches, the use of multiple coders and the coherence between the coders increase the reliability (Creswell, 2012). Within the scope of the present study, coding was requested from different coders. Besides, the principles such as being impartial in determining parents to be included, informing parents about the purpose of the research, basing on volunteering in the data collection process, using coding such as Mother 1 (M1), Father 1 (F1) in order not to use the real names were taken into consideration.

\section{Findings}

Opinions on early intervention were analyzed according to the opinions of parents having children with special needs in early childhood, and 6 themes were formed in this direction.

\section{Theme 1- The first time that parents learn about} their child's situation: The theme regarding the first time that parents learn about their child's situation that was formed according to the opinions of parents whose children were in need of special education consists of five categories. The categories are listed as: pregnancy period, infancy period, nursery period, kindergarten period and first grade period. Sample parental views on these categories are given in Table 2.

Table 2. Parents' Views on the first period that they learn about their child's condition

\begin{tabular}{|c|c|c|c|}
\hline Themes & Categories & $\begin{array}{l}\text { The Number } \\
\text { Parents }\end{array}$ & $\begin{array}{l}\text { Views of parents who have children requiring special education in early } \\
\text { childhood (M for Mother and F for Father) }\end{array}$ \\
\hline \multirow{5}{*}{ 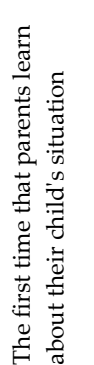 } & Pregnancy period & 4 & "Learned during pregnancy after the test" (M9) \\
\hline & Babyhood (0-2) & 15 & $\begin{array}{l}\text { "She was } 2 \text { and was not walking" (M4) } \\
\text { "Learned when s/he was born" (F17) }\end{array}$ \\
\hline & Nursery (3-4) & 10 & $\begin{array}{l}\text { "He was } 24 \text { months, learned it when we went to the psychiatrist" (M18) } \\
\text { "We found out when we went to the psychiatrist. He was about three years old } \\
\text { then" (F3) }\end{array}$ \\
\hline & Kindergarten (5-6) & 12 & $\begin{array}{l}\text { "We noticed it in kindergarten because she was behind his/her peers" (M3) } \\
\text { "I learned when s/he started kindergarten" (F20) }\end{array}$ \\
\hline & First Grade (7) & 12 & $\begin{array}{l}\text { "We just learned, he just recently started school" (M22) } \\
\text { "When I went to the psychiatrist with warning of the class teacher" (F13) }\end{array}$ \\
\hline
\end{tabular}

Theme 2- The first person and/or institution contacted when the child's special situation is learned: The theme consists of four categories: private special education and rehabilitation center, the teacher in the official school that child attended, guidance service of the school that child attended and hospital/doctor. Sample parental views on these categories are given in Table 3.

Table 3. Parents' Views on "The Person and/or Institution They First Apply to When They Learned About their Child's Condition"

\begin{tabular}{|c|c|c|c|}
\hline Themes & Categories & $\begin{array}{l}\text { The Number } \\
\text { Parents }\end{array}$ & $\begin{array}{l}\text { Views of parents who have children requiring special education in early } \\
\text { childhood (M for Mother and } \mathrm{F} \text { for Father) }\end{array}$ \\
\hline \multirow{4}{*}{ 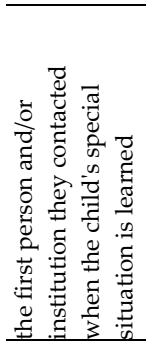 } & $\begin{array}{l}\text { Private special education and } \\
\text { rehabilitation center }\end{array}$ & 7 & $\begin{array}{l}\text { "We had some problems with his brother too, I brought him directly to } \\
\text { rehabilitation" (M13) } \\
\text { "I applied to special education school, I heard before that children like this go } \\
\text { there" (F1) }\end{array}$ \\
\hline & $\begin{array}{l}\text { The teacher in the official school that } \\
\text { child attended }\end{array}$ & 7 & $\begin{array}{l}\text { "I talked to her teacher and she guided us" (M9) } \\
\text { "We talked to the teacher at the school" (F15) }\end{array}$ \\
\hline & $\begin{array}{l}\text { The guidance service of the school } \\
\text { thaat child attended }\end{array}$ & 5 & $\begin{array}{l}\text { "I talked to our school counselor first" (M25) } \\
\text { "We met with the counsellor of the school" (F7) }\end{array}$ \\
\hline & Hospital/doctor & 34 & $\begin{array}{l}\text { "I went to the risky pregnancy department at the hospital" (M1) } \\
\text { "We first took her/him to the psychologist" (F5) }\end{array}$ \\
\hline
\end{tabular}


Theme 3- The meaning of early intervention: The meaning of early intervention theme consists of seven categories: education starting during pregnancy, the service provided to the family after diagnosis, taking precautions before the problem occurs/early diagnosis, the early recognition of parents and educators, future, success, starting treatment/education/diagnosis at an early age for the current situation/problem. Sample parental views on these categories are given in Table 4 .

Table 4. Parents' Views on the "Meaning of Early Intervention"

\begin{tabular}{|c|c|c|c|}
\hline Themes & Categories & $\begin{array}{l}\text { The Number } \\
\text { Parents }\end{array}$ & $\begin{array}{l}\text { Views of parents who have children requiring special education in early } \\
\text { childhood (M for Mother and F for Father) }\end{array}$ \\
\hline \multirow{7}{*}{ 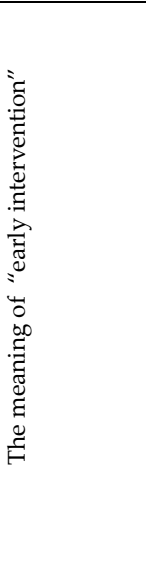 } & Education starting during pregnancy & 4 & "An education that includes the whole family begins in the womb." (M1) \\
\hline & $\begin{array}{l}\text { The service provided to the family } \\
\text { after diagnosis }\end{array}$ & 6 & $\begin{array}{l}\text { "To learn more about my child's illness" (F23) } \\
\text { "One-on-one early education, family support and guidance come to my mind" } \\
\text { (M19) }\end{array}$ \\
\hline & $\begin{array}{l}\text { Taking precautions before the problem } \\
\text { occurs/early diagnosis (Preventive } \\
\text { intervention) }\end{array}$ & 12 & $\begin{array}{l}\text { "Before it is too late, the precautions should be taken and/or the intervention } \\
\text { should be applied, otherwise it is too late" (F5) } \\
\text { "I think it is possible to overcome the problems with early detection and we should } \\
\text { not let fear get us" (M14) }\end{array}$ \\
\hline & $\begin{array}{l}\text { Early recognition of parents and } \\
\text { educators }\end{array}$ & 5 & $\begin{array}{l}\text { "Parents and the environment should be careful so that the child's condition does } \\
\text { not progress, she should be taken to the doctor immediately." (F15) } \\
\text { "We as mothers notice things and have more productive results" (M20) }\end{array}$ \\
\hline & Future & 4 & "Early diagnosis means future" (M8) \\
\hline & Success & 8 & $\begin{array}{l}\text { "Keeping up with her/his friends without lagging behind in education" (F18) } \\
\text { "To me it is shortly 'success" " (M6) }\end{array}$ \\
\hline & $\begin{array}{l}\text { Starting treatment/education early for } \\
\text { the current situation/problem/ } \\
\text { diagnosis at an early age }\end{array}$ & 14 & $\begin{array}{l}\text { "When it found out at an early age, more information can be acquired." (F11) } \\
\text { "In my opinion, training should start early, at a young age, before it is too late." } \\
\text { (M26) }\end{array}$ \\
\hline
\end{tabular}

Theme 4- The difficulties they experienced during the diagnosis and/or after diagnosis: The theme regarding the difficulties parents experienced during and/or after diagnosis consists of six categories. These categories are as follows: reporting process, not providing the necessary guidance service to the family, inadequacy in the education given to the child, difficulty in accepting, adapting to the social environment, fear and anxiety caused by the unknown and the future. Sample parental views on these categories are given in Table 5.

Table 5. Parents' Views on the Difficulties They Experienced during and/or after the Diagnosis

\begin{tabular}{|c|c|c|c|}
\hline Themes & Categories & $\begin{array}{l}\text { The Number } \\
\text { Parents }\end{array}$ & $\begin{array}{l}\text { Views of parents who have children requiring special education in early } \\
\text { childhood ( } M \text { for Mother and } F \text { for Father) }\end{array}$ \\
\hline \multirow{6}{*}{ 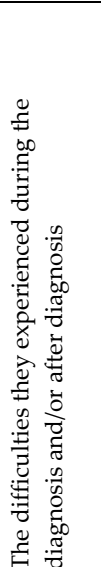 } & Reporting process & 5 & $\begin{array}{l}\text { "In this process, we had difficulties especially in reporting and then in } \\
\text { education practices." (F13) } \\
\text { "I was psychologically down while getting a report" (M7) }\end{array}$ \\
\hline & $\begin{array}{l}\text { Not providing the necessary } \\
\text { guidance service to the family }\end{array}$ & 11 & $\begin{array}{l}\text { "We also struggled to find the right educational institution" (F20) } \\
\text { "I really need to be guided right" (M17) }\end{array}$ \\
\hline & $\begin{array}{l}\text { Inadequacy in the education given } \\
\text { to the child }\end{array}$ & 9 & $\begin{array}{l}\text { "We are having difficulties in the education of our child" (F9) } \\
\text { "When I wanted to get private lessons for my child, some people said, 'She is a } \\
\text { baby, what are we going to teach her?" (M1) }\end{array}$ \\
\hline & Difficulty in accepting & 8 & $\begin{array}{l}\text { "It was hard to accept" (F22) } \\
\text { "It was hard times and it is still tough sometimes. I had a hard time accepting } \\
\text { it" (M19) }\end{array}$ \\
\hline & $\begin{array}{l}\text { Adapting to the social } \\
\text { environment }\end{array}$ & 14 & $\begin{array}{l}\text { "He had trouble adapting with her peers, the people around were asking } \\
\text { whether she was going to rehabilitation or not. I had a lot of trouble" (F1) } \\
\text { "It makes me very sad not receiving any support from the environment and } \\
\text { the people in the society are not taking responsibility" (M10) }\end{array}$ \\
\hline & $\begin{array}{l}\text { Fear and anxiety caused by the } \\
\text { unknown and the future }\end{array}$ & 6 & $\begin{array}{l}\text { "There are things that are unknown and as a result I have fear and } \\
\text { incompatibilities" (M24) }\end{array}$ \\
\hline
\end{tabular}

Theme 5- The method of dealing with difficulties:

The theme of dealing with difficulties has seven 
categories: continuous struggle without giving up, having support education for the child, being in constant cooperation with the school the child was attending, leaving it to time and helping with his own competence, interview and psychological support, patience/calmness and supporting each other in the family. Sample parental views on these categories are given in Table 6.

Table 6. Parents' Views on Struggling with the Difficulties they Faced

\begin{tabular}{|c|c|c|c|}
\hline Themes & Categories & $\begin{array}{l}\text { The Number } \\
\text { Parents }\end{array}$ & $\begin{array}{l}\text { Views of parents who have children requiring special education in early } \\
\text { childhood (M for Mother and F for Father) }\end{array}$ \\
\hline \multirow{7}{*}{ 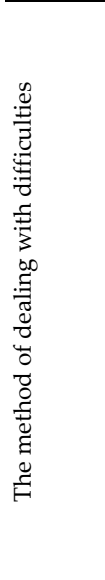 } & $\begin{array}{l}\text { Continuous struggle without giving } \\
\text { up }\end{array}$ & 7 & $\begin{array}{l}\text { "Fighting" (F2) } \\
\text { "By not giving up and fighting even fighting" (M1) }\end{array}$ \\
\hline & $\begin{array}{l}\text { Having support education for the } \\
\text { child }\end{array}$ & 10 & $\begin{array}{l}\text { "For my child to get education" (F6) } \\
\text { "Going to rehabilitation has given us strength" (M8) }\end{array}$ \\
\hline & $\begin{array}{l}\text { Being in constant cooperation with } \\
\text { the school the child was attending }\end{array}$ & 9 & $\begin{array}{l}\text { "We consulted our child's teacher, talking to her/him was especially good for my } \\
\text { wife." (F20) } \\
\text { "I coped with my problems in cooperation with the teacher" (M5) }\end{array}$ \\
\hline & $\begin{array}{l}\text { Leaving it to time and helping with } \\
\text { his own competence }\end{array}$ & 11 & $\begin{array}{l}\text { "I constantly supported and helped my child, it got better over time" (F17) } \\
\text { "I let it go and try to do the right thing in my own way" (M27) }\end{array}$ \\
\hline & Interview and psychological support & 3 & $\begin{array}{l}\text { "We met with the families of our child's friends" (F3) } \\
\text { "I had difficulty during the report process, received psychological support, both } \\
\text { from the institution and the public hospital" (F16) }\end{array}$ \\
\hline & Patience/calmness & 10 & $\begin{array}{l}\text { "With patience and fortitude" (F14) } \\
\text { "I prayed, paid close attention to everything, autosuggested and was patient" } \\
\text { (M30) }\end{array}$ \\
\hline & Supporting each other in the family & 3 & $\begin{array}{l}\text { "We tried to get over it with my mother's support, they went to school together } \\
\text { with her, and we all got used to it." (M13) }\end{array}$ \\
\hline
\end{tabular}

Theme 6- The suggestions to difficulties encountered in early intervention: The theme consists of seven categories: Guidance service for the family, continuous education service for the child and family during and after pregnancy, public consciousness, parents having high awareness, teachers being attentive and knowledgeable, early treatment and the correct guidance of healthcare professionals and the last one is psychological support category. Sample parental views on these categories are given in Table 7.

Table 7. Parents' Advice about the Difficulties they Experienced durin Early Intervention

\begin{tabular}{|c|c|c|c|}
\hline Themes & Categories & $\begin{array}{l}\text { The Number } \\
\text { Parents }\end{array}$ & $\begin{array}{l}\text { Views of parents who have children requiring special education in early } \\
\text { childhood (M for Mother and F for Father) }\end{array}$ \\
\hline$\underset{\overparen{D}}{\stackrel{0}{D}}$ & Guidance service for the family & 9 & $\begin{array}{l}\text { "By raising families' awareness" (F4) } \\
\text { "The problem does not go any further when intervened early. Families should be } \\
\text { more informed and guided on this." (M13) }\end{array}$ \\
\hline 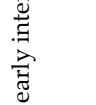 & $\begin{array}{l}\text { Continuous education service for the } \\
\text { child and family during and after } \\
\text { pregnancy }\end{array}$ & 20 & $\begin{array}{l}\text { "It can be prevented through education because it starts at home" (F1) } \\
\text { "I found out that my child had Down syndrome when I was pregnant, so } \\
\text { education should start right from that moment." (M1) }\end{array}$ \\
\hline 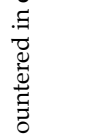 & Public consciousness & 4 & $\begin{array}{l}\text { "When people not undermine the child and when they accept..." (F7) } \\
\text { "If the families of other children as well as families of children in need of special } \\
\text { education are made aware of the issue, the prejudice and exclusion in the society } \\
\text { can be eliminated." (M17) }\end{array}$ \\
\hline $\begin{array}{l}\tilde{y} \\
\tilde{D} \\
\mathscr{D}\end{array}$ & Parents having high awareness & 8 & $\begin{array}{l}\text { "It is prevented by mothers and fathers understanding everything well" (F21) } \\
\text { "It is important for families to be more conscious and informed in advance." (M2) }\end{array}$ \\
\hline 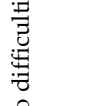 & $\begin{array}{l}\text { Teachers being attentive and } \\
\text { knowledgeable }\end{array}$ & 4 & $\begin{array}{l}\text { "Can be avoided by meeting a good teacher" (F22) } \\
\text { "In kindergarten, the teacher can be more careful, and should not make } \\
\text { comparisons" (M10) }\end{array}$ \\
\hline 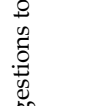 & $\begin{array}{l}\text { Early treatment and the correct } \\
\text { guidance of healthcare professionals }\end{array}$ & 3 & $\begin{array}{l}\text { "With early recognition and immediate treatment" (F12) } \\
\text { "Doctors should be more conscious, tell us to get a report, make us buy and use a } \\
\text { device immediately." (M30) }\end{array}$ \\
\hline 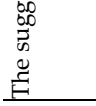 & Psychological support & 5 & $\begin{array}{l}\text { "Time is the best healer, psychological support is also needed" (F16) } \\
\text { "After the doctors explain the situation of our child, they should provide } \\
\text { psychological support to us." (M15) }\end{array}$ \\
\hline
\end{tabular}

\section{Discussion and Conclusion}

In this study, we aimed to get the opinions of parents who have children with special needs about early intervention because the existence of any negative situation or the risk of negativity that may affect the whole life of the individual makes the first steps, early diagnosis and early 
intervention very important. Evaluations should be made in the family environment, which is the most important environment for children in early childhood, involving parents and referring to their experiences and knowledge. For this reason, it is very important for parents having children with special needs how they overcome this period, and get support regarding the right solutions they need.

The first finding of the study is the categories created for the theme of the first learning period of the child's situation. These categories are listed as pregnancy period, infancy period, nursery period, kindergarten period and first grade period. In recent years, early diagnosis has proven its importance for children with special needs in benefitting from early intervention services. Diagnosing some disability groups during pregnancy and infancy provides important contributions for parents (Ciğerli, Topsever, Alvur and Gölperioğlu 2014; García-Grau, MartínezRico, McWilliam and Cañadas Pérez 2020). Early identification of the child's special needs provides a chance to benefit from early intervention services and education programs.

Studies have shown that education started in early childhood increases the developmental skills of both children in the risk group and children with special needs (Acar \& Akamoğlu 2014; Aslan 2015; Doğan 2012; Gökmen et al., 2016; Kılınç \& Aral 2015; Shelleby \& Ogg 2020; Yıldırım Doğru, 2017). Selimoğlu and Özdemir (2018) examined the effectiveness of the Interaction-Based Early Childhood Intervention Program (IBECIP) on social interaction skills of 6, 4, and 3-year-old children with autism spectrum disorder. At the end of the study, it was determined that children showed improvements in social interaction skills. In the early period, the participation of parents in intervention programs for their children with special needs depends on their own or referral (García-Grau, Martínez-Rico, McWilliam \& Cañadas Pérez, 2020; Gül \& Diken, 2009; Özkan, 2020; Yildırım Doğru, 2017). Therefore, educational support provided for parents about the early developmental characteristics of children, how to recognize a special situation, and when to consult a specialist will prevent delays in the field of special education.

According to the opinions of parents who have children with special needs in early childhood, the institution/person they mostly turn to in the early intervention process has been the hospital and the doctor. Research findings also reveal similar results (Çitil \& Doğan 2019; Ercan, Kırlıoğlu \& Kalayc1-Kırlığlu 2019). In this case, parents have to deal with this situation according to their own experiences, especially if formal psychological support is not provided. In addition, if a difference is observed in the nursery and/or school environment, it is seen that the parents expect support or guidance of classroom teachers. In their study, Küçük-Doğaroğlu and Bapoğlu-Dümenci (2015) stated that preschool teachers stated that inclusion is an early intervention and it is the evaluations and interventions to be planned for children in the risk group. They also stated that if there is a problem with development in early childhood, all procedures related to diagnosis and education should be included in early intervention services. It is emphasized that preschool teachers cover an important period in early intervention programs in terms of the development period of the group they teach, and the importance of cooperation with them (Bari et al. 2016). Therefore, both healthcare professionals and people involved in education should be equipped with early intervention for medical, psychological and educational services to be provided to parents.

The reseach finding related to what early intervention is revealed the importance of correctly defining early intervention as a concept and practice. Parents have demonstrated their awareness of the implementation steps of early intervention by mentioning both the preventive and intervention dimensions (García-Grau et al., 2020). Since carrying out early intervention studies with their preventive and interventional aspects can be considered as important steps in fulfilling the requirements of the early intervention spirit (Akoğlu \& Şipal, 2012; Aytekin, 2016; Karoly, Kilburn \& Cannon 2005). In the research findings, parents' views on the correct understanding of early intervention sheds light on the problems in this area. Temiz and Akman (2015), in their 
research examining the views of scientists contributing to early intervention, determined that they focused on "preventive and timely intervention, intervention in developmental problems" in the definition of early intervention.

Parents having children with special needs show different reactions when they learn about their child's special situation. These reactions and emotional states starting with shock and denial, pass through different stages until the acceptance stage (Ardıç 2013; Ercan, Kırlıoğlu, \& Kalayc1Kırlıoglu 2019). Adverse reactions from the social environment are not only quite weary in this regard, but also push the parents into a defensive and/or introverted position (Gül, Erberk-Özen \& Battal, 2017). When the environment has an accepting attitude towards the parent and child, it helps them come out stronger from the process. In addition, the anxiety caused by the unknown and not knowing what awaits them in different situations cause negativities for the parents. Therefore, it is very important to support parents psychologically and to direct them by regularly evaluating their children's development in order to contribute directly to their education (Arıcıoğlu ve Gültekin, 2017; Özkan, 2020; Selimoğlu, Özdemir, Töret ve Özkubat, 2014). Being aware of the development of their child and having information and ideas about what they should do to increase their strengths will enable parents to progress towards more realistic goals and to be more active in the team.

The theme of dealing with difficulties has seven categories. The most emphasized categories were receiving support education for the child, being in constant cooperation with the school s/he attended, leaving it to time and helping with his/her own competence. Achieving the right care in time during the early intervention period is vital for parents. Because it is necessary to determine the developmental level of the child and to provide appropriate support with early intervention if s/he is in the risk group according to this level, and to be supported in line with the areas where his/her potential is open to development (Powell, 2019; Tunçeli \& Zembat, 2017). Benefiting from early intervention services according to the developmental characteristics of their children and being in cooperation with service providers has been another issue emphasized for parents in this process. However, parents who cannot get the necessary support in the official or social environment, especially at the first stage, try to find a solution within themselves. However, in order to achieve success in early intervention studies; observing families and children in their natural environments, evaluating their needs realistically, an individualized family service plan (BAHP) and individual education programs (IEP) should be prepared for each child and his family (Akoğlu \& Şipal, 2012; Değirmenci \& Karahisar, 2015; İlik \& Günay, 2020) ; Powell, 2019). Campbell and Halbert (2009) found that high-quality education for children with special needs is through early intervention practices and it is stated that early intervention programs should be prepared for parents and their participation in the programs should be ensured. In Turkey, services are designed especially for children aged $0-3$ in a way that reaches every child and their families, to ensure the welfare of children with special needs, to plan services that are suitable for their developmental characteristics, and to increase cooperation with all service providers (https://ailevecalisma.gov.tr/). However, sometimes not being able to define their needs correctly and the inadequacy of the psychological support provided can make cooperation with the parents difficult. For instance, Bruder, Dunst, and Mogro-Wilson (2011) conducted a study with 1800 experts working in the field of early intervention and found that the participants failed to establish and maintain their cooperation with their parents. Therefore, it is suggested that needs should be analyzed carefully. In Atkins' (2008) study that included special education teachers and techers from other branches, it is emphasized that teachers should receive support and encouragement from parents to carry out intervention activities.

The theme of recommendations for the difficulties experienced in early intervention was created according to the views of parents, who constitute an important link in early intervention practices. Their suggestions based on the experience they have gained from their experiences contribute to a more efficient process. Parents need to have the correct information about the normal structure to cope with a different 
situation. For this, guidance services should be provided to parents. In addition, parents especially emphasize that the continuous and systematic education programs offered in early childhood will provide a high level of benefit in terms of early intervention and support their children's development without interruption (Doğan ,2012; Erdil, 2010; Öncül, 2014).

In the findings obtained from the research, the current situation within the scope of early intervention has been determined. The experiences of parents having children with special needs in early intervention practices and programs are presented and discussed. Early intervention is a practice in which parents make a great contribution and should be carried out in collaboration with multifaceted service providers. For this reason, it requires every supporter who brings together multi-faceted subjects and different areas of expertise and takes part in the application to be equipped. Professional competencies and standards of people who will work in early childhood intervention programs should be well defined. Although it varies according to the type of disability and risk group of the process, it is recommended as a great necessity to establish comprehensive and integrated early intervention systems for parents in both health institutions and educational institutions. In order for these practices to be carried out without interruption and in a qualified manner, it is suggested that early intervention studies should be secured by laws, the steps to be followed and the studies to be carried out should be systematically determined and disseminated. Thus, studies conducted with a systematic early intervention model according to cultural characteristics will provide the most effective results in the earliest time.

Early intervention programs developed according to needs and cultural characteristics can be developed for more active participation of children with special needs and risk groups in life. Longitudinal studies can be conducted on the long-term effects of these developed programs. Early intervention applications and programs can be formed according to different special needs.

\section{Limitations}

In evaluating the implementation of early intervention services, the opinions of the participants were evaluated using only the interview technique among qualitative research techniques. The combination of different methods and techniques that require a lot of time can be weary for this emotionally sensitive group of parents. In addition, the findings obtained from the research are limited to the opinions of the participants included in this study.

\section{Ethical statement}

The study data were obtained from mothers who volunteered to participate in the study between September-November 2019. The data presented in the study are in accordance with academic and ethical rules. All evaluations and results are presented in accordance with scientific ethics and moral rules.

\section{Acknowledgements}

I would like to thank the parents who participated in the study and provided the present data. I also appreciate the time that the reviewers of the journal for their precious comments.

\section{Declaration of Conflicting Interests}

The author declared no potential conflicts of interest whith respect to the research, authorship, and/or publication of this article.

\section{Funding}

This research did not receive any specific grant from funding agencies in the public, commercial or not-for-profit sectors.

\section{References}

Acar, S. \& Akamoğlu Y. (2014). Practices for parent Participation in early intervention/early childhood special education. International Journal of Early Childhood Special Education 
(INT-JECSE),

$6(1)$

doi:10.20489/intjecse.93010.

Akoğlu, G. \& Şipal, R.F. (2012). Early intervention approaches for children in low socioeconomic status: Applications from the World and Turkey. Community and Service, 23(1), 213-224.

Alduhaim, A., Purcell, A., Cumming, S. \& Doble, M. (2020). Parents' views about factors facilitating their involvement in the oral earlyintervention services provided for their children with hearing loss in Kuwai. International Journal of Pediatric Otorhinolaryngology, 128, 1-9. doi: 10.1016/j.ijporl.2019.109717.

Ardıç, A. (2013). Family education and guidance in special education. In: Cavkaytar A. (eds) Children with Special Needs and Their Families. Ankara: Vize Publishing.

Arıcıoğlu, A. \& Gültekin, F. (2017). Social support and future perceptions of mentally handicapped children: The role of psychological counselors. Journal of Mehmet Akif Ersoy University Faculty of Education, 42, 1-26. doi:10.21764/efd.31545

Aslan, K. (2015). Compilation of early symptoms of specific learning disabilities and early intervention practices. Hacettepe University Faculty of Health Sciences Journal, 1, 577-588.

Atkins, T. (2008). A case study examining the collaboration between general education and special education teachers in inclusive classrooms, institution: Mississippi State University. PhD Thesis. The Faculty of Mississippi State University, Mississippi.

Aytekin, Ç. \& Bayhan, P. (2015). Application steps in early intervention. H.U. Journal of the Faculty of Health Sciences, 2(2), 1-14.

Aytekin, Ç. (2016). Examining the postgraduate dissertations regarding early intervention concept in Turkey. Occupational Therapy and Rehabilitation Journal, 4(2), 115-128.

Bağlama, B. \& Sakall1-Demirok, M. (2016). Determination of preservice special education teachers' view early childhood intervention. Cypriot Journal of Educational Sciences, $\quad 11(4)$ 213-222. DOI:10.18844/cjes.v11i4.1297.

Bailey, D. J. \& Wolery, M. (2007). Early childhood special education research. Journal of Early Intervention, 25(2), 88-99.
Baltac1, A. (2019). Qualitative research process: How is a qualitative research conducted?. Ahi Evran University Journal of Social Sciences Institute (AEÜSBED), 5(2) 368-388. doi:10.31592/aeusbed.598299.

Bari, S., Abdullah, N. A., Abdullah, N. \& Yasin, M.H.M. (2016). Early intervention implementation preschool special education students in Malaysia. International Journal for Innovation Education and Research, 4(6), 139155.

DOI: https://doi.org/10.31686/ijier.vol4.iss7.569.

Bate, A. (2017). Early intervention, House of Commons Library (Commons Library Briefing, 26 June 2017). URI: https://dera.ioe.ac.uk/id/eprint/30984.

Brott, P. E. \& Myers, J. E. (2002). Development of professional school counselor identity a grounded theory. In: S. B., Merriam et al. (eds). Qualitative research in practice examples for discussion and analysis (p.145-160), San Francisco: Jossey-Bass A Wiley Company.

Bruder, M.B., Dunst, C.J. \& Mogro-Wilson, C. (2011). Confidence and competence appraisals of early intervention and preschool special education practitioners. International Journal of Early Childhood Special Education, 3(1), 1337.

Campbell, P. H. \& Halbert, J. (2002). Between research and practice: provider perspectives on early intervention. Topics in Early Childhood Special Education, 22(4), 213-226. doi.org/10.1177/027112140202200403.

Campbell, P.H. \& Sawyer, L.B. (2009). Changing early intervention providers' home visiting skills through participation in professional development. Topics in Early Childhood Special Education, 28(4), 219-234. doi.org/10.1177/0271121408328481.

Ciğerli, Ö., Topsever, P., Alvur, M. \& Görpelioğlu, S. (2014). Parenting experiences of parents with disabled children from the time of diagnosis: Accepting the difference. Turkish Journal of Family Medicine and Primary Care (TJFMPC), 8(3), 75-81.

Coolican, H. (1992). Research methods and statistics in psychology. London: Hodder \& Stougtton.

Creswell, J. W. (2012). Educational research: planning, conducting, and evaluating quantitative and qualitative research. Fourth Edition. Boston: Pearson. 
Çitil, M. \& Doğan, İ. (2019). Determination of the structure and social relations of families with disabled children. Journal of Social Policy Studies, 43, 2148-9424. doi.org/10.21560/spcd.v19i46288.453941.

Değirmenci, G.Y. \& Karahisar, S. (2015). A model for family-centered practices in early intervention programs: National Early Intervention Longitudinal Study (NEILS), USA. Hacettepe University Faculty of Health Sciences, 1, 695-704.

Diken, İ. H., Bayhan, P., Turan, F., Sipal, R.F., Sucuoğlu, B., Ceber-Bakkaloğlu, H., Günel, M.K. \& Kara, O.K. (2012). Early childhood intervention and early childhood specialeducation in Turkey within the scope of the developmental system approach. Infants \& Young Children, 25(4), 346-353. doi: 10.1097/IYC.0b013e318268541d.

Doğan, H. 2(012). The study of the effects of early intervention education program for 5-6 year-old children with special learning difficulty. Unpublished $\mathrm{PhD}$ dissertation. Marmara University Institute of Educational Sciences, Istanbul.

Eisenhower, A., Pedraza, F.M., Sheldrick, R.C., Frenette, E. Hoch, N., Brunt, S. \& Carter, A.S. (2020). Multi-stage screening in early intervention: A critical strategy for improving asd identifcation and addressing disparities. Journal of Autism and Developmental Disorders, 51, 868-863. doi.org/10.1007/s10803-020-04429-z.

Ercan, F.Z., Kırlığlu, M. \& Kalaycı-Kırlıoğlu, H.i. (2019). The acceptance process of families with disabled children and their views on this situation. Journal of Social Policy Studies, 44 ,

2148-9424.

doi.org/10.21560/spcd.v19i49119.459666.

Erdil, Z. (2010). Children that are socioeconomically at risk: The relationship between early intervention programs and their academic achievement. Faculty of Health Sciences Nursing Journal, 72-78.

García-Grau, P., Martínez-Rico, G., McWilliam, R.A. \& Cañadas Pérez, M. (2020). Typical and ideal practices in early intervention in spain during a transformation process of professional practices. Journal of Early Intervention 2020, 42(1), 3-19. doi.org/10.1177/1053815119859046.
Gökmen, A, Devecï, H, Bïngöl, K, Bekïr, H, Temel, Z.F. \& Kanat, K. (2016). Study of the relationship between preschool teachers' high scope approach beliefs and beliefs of self-efficacy. Kastamonu Education Journal, 24(5), 2481-2500.

Gül, A., Gül, H., Erberk Özen, N. \& Battal, S. (2017). Differences between childhood traumatic experiences and coping styles for male and female patients with major depression. Turkish Journal of Psychiatry, 28(4), 1-9. DOI:10.5080/u18193.

Gül, S.O. \& Diken, İ.H. (2009). Reviewing graduate studies regarding early childhood special education in Turkey. InternationalJournal of Early Childhood Special Education, 1(1), 46-78. doi.org/10.20489/intjecse.107977.

Gürel Selimoğlu, Ö. \& Özdemir, S. (2018). The effectiveness of the interaction-based early childhood intervention program (EIBECIP) on the social interaction skills of children withaAutism spectrum disorder. Journal of Early Childhood Studies, 2(3), 514-555. doi.org/10.24130/eccd-jecs.196720182399.

Gürel Selimoğlu, Ö., Özdemir, S., Töret, G., and Özkubat, U. (2014). Examination of the opinions of parents with autistic children about their experiences during and after the diagnosis of autism. International Journal of Early Childhood Special Education, 5(2), 129167. doi.org/10.20489/intjecse.107930.

İlik, Ş. Ş. \& Günay, Y. E. (2020). Examining the opinions of teachers on the IEP practices preferred in the process of preparing an individualized education program. Journal of Bayburt Faculty of Education, 15(30), 347-362. https://doi.org/10.35675/befdergi.728139.

Karoly, L.A., Kilburn, M.R. \& Jill, C.S. (2005). Early childhood intervention-proven results, future promise. Santa Monica: Rand Corporation.

Kennedy, A., McLoughlin, J., Moore, T., GavidiaPayne, S. \& Forster, J. (2011). Early childhood intervention reform project, published by programs and partnerships division department of education and early childhood development, Australia: Melbourne.

Kılıçkaya, A. \& Zelyurt, H. (2015). Study of the inclusion of individuals with special needs in preschool programs (1989-2013). International Journal of Turkish Educational Sciences, 2015(4), 200-212. 
Kılınç, F.E. \& Aral, N. (2015). A Model for early intervention: Mother child interaction program. Hacettepe University Faculty of Health Sciences Journal, 1, 63-76.

Küçük Doğaroğlu, T. \& Bapoğlu Dümenci, S.S. (2015). Study of preschool teachers' views on inclusive education and early intervention in their classrooms. Hacettepe University Faculty of Health Sciences Journal, 1, 460-473.

Öncül, N. (2014). Revision of the early childhood special education related articles conducted in Turkey. International Journal of Early Childhood Special Education (INT-JECSE), 6(2), 247-284. DOI:10.20489/intjecse.75598.

Özkan, İ. (2020). Early intervention and its importance. In: Özyürek, A. and Sezgin, E. (eds.), Early intervention in childhood, Ankara: Nobel publishing.

Pang, Y. \& Richey, D. (2005). A Comparative study of early intervention in Zimbabwe, Poland, China, India, and The United States of America. The International Journal of Special Education, 20(2), 122-131. ISSN-0827-3383.

Powell, T. (2019). Early intervention, Commons Library Briefing, 11 July 2019, copright San Mateo Country Libraries.June2021https://researchbriefings.files.parliament.uk/docu ments/CBP-7647/CBP-7647.pdf.

Pretis, M. (2009). Early childhood intervention in austria: an overview of 30 years of development and future challenges. International Journal of Early Childhood Special Education (INT-JECSE), 1(2), 127-137. doi.org/10.20489/intjecse.107982.

Reynolds, A. J., Temple, J. A. \& Ou, S-R. (2003). School-Based early intervention and child well-being in the chicago longitudinal study. Child Welfare, 32(5), 633-656. PMID: 14524429

Reynolds, A.J. (2000). Success in early intervention., United States of America: University of Nebraska Press.

Sandberg, A., Norling, M. \& Lillvist, A. (2009). Teachers $^{\text {ee }}$ view of educational support to children in need of special support. International Journal of Early Childhood Special Education (INT-JECSE), 1(2), 102-116.
Sazak- Pınar, E. (2006). Development of early childhood special education in the World and Turkey and early childhood special education applications. Ankara University Faculty of Educational Sciences Journal of Special Education, 7(2), 71-83. doi.org/10.1501/Ozlegt 0000000098.

Shelleby, E.C. \& Ogg, J. (2020). Longitudinal relationships between parent involvement, parental warmth, adhd symptoms, and reading achievement. Journal of Attention Disorders, 24(5), 737-749. DOI: $\underline{10.1177 / 1087054719859075}$

Tavşancıl, E., \& Aslan, E. (2001). Content analysis and sample practices for verbal, written and other materials. İstanbul: Epsilon Publications.

Temiz, N. \& Akman, B. (2015). Evaluations of scientists regarding knowledge, definition and roles of early intervention in early childhood period. Hacettepe University Faculty of Health Sciences Journal, 1, 30-47.

Tunçeli, H.İ. \& Zembat, R. (2017). Evaluation and importance of development in early childhood period. Journal of Educational Theory and Practice Research, 3(3), 1-12.

Yıldırım, A., \& Şimşek, H. (2005). Qualitative research methods in social sciences. Ankara: Seçkin Publishing.

Yıldırım Doğru, S.S. (2017). Alternative program in special education special education program for children from birth to six years old, The Journal of International Education Science, 4 (10), 326-343.

Zheng, Y., Maude, S.P. \& Brotherson, M.J. (2015). Early childhood intervention in China. Journal of International Special Needs Education, 18(1), 29-39. DOI:10.9782/2159-4341-18.1.29.

https://ailevecalisma.gov.tr. Date of access: September 2021. 